\title{
The Effects of Performance Expectancy, Effort Expectancy, Facilitating Condition, and Habit on Behavior Intention in Using Mobile Healthcare Application
}

\author{
Prio Utomo $^{1)}$, Florentina Kurniasari*2), Purnamaningsih Purnamaningsih ${ }^{3)}$ \\ 1,2) Technology Management Department, Universitas Multimedia Nusantara, Indonesia \\ 3) Management Department, Universitas Multimedia Nusantara, Indonesia \\ *Correspondence Author: florentina@umn.ac.id ${ }^{2}$
}

\begin{abstract}
South Tangerang Health Office had the responsibility in giving outstanding healthcare services to its resident's despite of its limitation due Covid-19 pandemic. Some programs were initiated to reduce maternal, babies and toddler mortality, and in the same time reduce the number of malnourished children. The integrated healthcare mobile application called Si Pandai Kemas TangSel had been launched and can be downloaded easily through smartphone. The study is expected to measure the effectiveness of Si Pandai Kemas TangSel using UTAUT approach by measuring the influence of performance expectancy, effort expectancy, facilitating condition and habit toward behavior intention in using Si Pandai Kemas TangSel mobile application. The study showed that the effort expectancy and habit can increase the intention to use Si Pandai Kemas TangSel application. Meanwhile, performance expectancy and facilitating conditions did not affect behavioral intention in using Si Pandai Kemas TangSel application.
\end{abstract}

Keywords: Performance Expectancy, Effort Expectancy, Facilitation Condition, Habit, Si Pandai Kemas TangSel

\section{Introduction}

Sustainable development is defined as a principled development on the fulfillment of human current needs without sacrificing the needs of future generations. In 2012, the concept of the Sustainable Development Goals (SDGs) was globally initiated by the United Nations Conference with the goal is to produce a universal set of goals to anticipate the environmental, political and economic challenges facing the world. The SDGs replace the Millennium Development Goals (MDGs), which began a global effort in 2000 to address poverty inequality (UNDP, 2016). Indonesia government also committed to implement this program by establishing Presidential Regulation Number 59 of 2017 on the Implementation of the Achievement of sustainable development goals on July 4, 2017 (BAPPENAS, 2017). 


\section{Sustainable Development Goals}

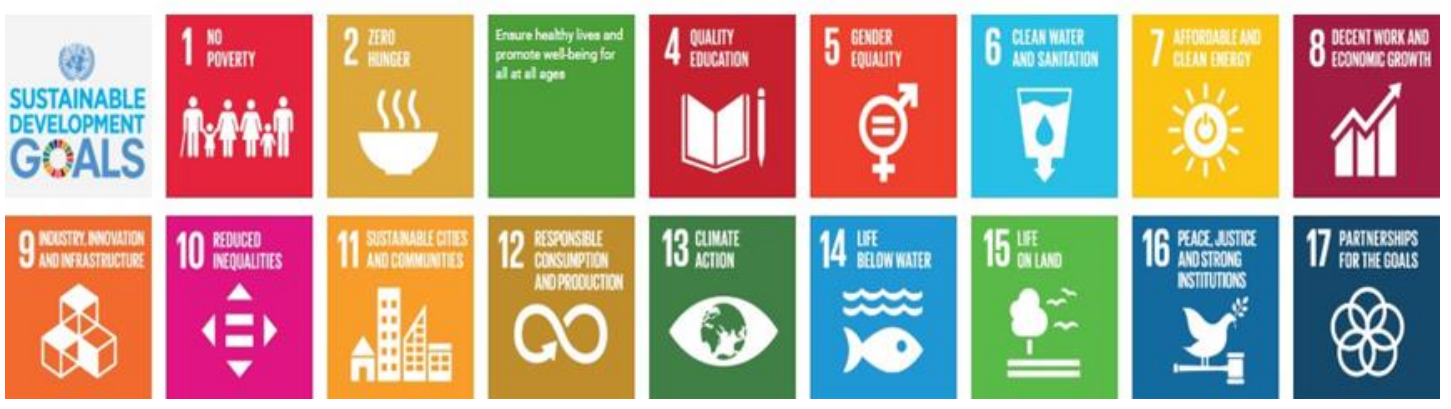

Source: UNDP (2016)

Figure 1. Sustainable Development Goals (United Nations, 2019)

One of the sustainable development goals adopted as Indonesia's national target (RPJMN) in 2015-2019 is the 3rd Global Goal on state guarantees to ensure all communities for healthy living (INFID, 2017). The implementation of health development outlined by the Government of Indonesia in the National Health System is directed so that the range of health services is wider and evenly distributed so that it can be accessed by all levels of society. Improving public health services is expected to improve the degree of public health and to allow people to live more productive lives, both economically and socially.

However, based on the global health index, Indonesia still ranks 101st out of a total of 149 countries. Indonesia's position, still below other Southeast Asian countries, such as Malaysia, Thailand, Laos and Vietnam (Deborah, 2017). According to Luthfi Mardiansyah as Founder and Chairman of the Center for Healthcare Policy and Reform Studies Chapters Indonesia, there are at least six obstacles that cause the health care system in Indonesia is still not maximal. One of the 6 main obstacles is the low quality of health services (kompas.com, 2019). The quality of health services is low today, reflected by the lack of number of medical personnel and the limited number of existing health facilities resulting in a large and far from ideal ratio of community handling by medical personnel. Many health facilities are not able to provide excellent services due to the lack of supporting infrastructure and the amount of human resources owned (Setiawati \& Nurrizka, 2019).

The main concern in providing healthcare services is related with the availability and affordability of health facilities, facilities and infrastructure that is can easily reach by residents. The rapid advancement in technology encourage government to establish government policy strategy in the field of national e-health (Ministry of Health, 2017). This is also experienced by the city of South Tangerang. The number of health facilities (Hospitals, Health Centers and Clinics or Health Centers and Puskesmas) in South Tangerang City in 2017 amounted to 470 units and must serve as many as 1.64 million residents (BPS Kota Tangerang Selatan, 2019). Of course, with the lack of number of health facilities available compared to the population of South Tangerang City, South Tangerang. The government of South Tangerang had set-up the strategies to improve the degree of public health through three indicators, namely the maternal mortality indicator per 100,000 live births, the infant mortality rate per 1000 live births and the rate of pain according to certain diseases per 100 populations. Only $83.63 \%$ of children under five years old had immunization cards and only $14.26 \%$ children have been fully immunized (South Tangerang City Kominfo Office, 2019). The declining trend of infant mortality rate showed the effort of the South Tangerang City Health Office in reducing infant mortality rate (Figure 2). 


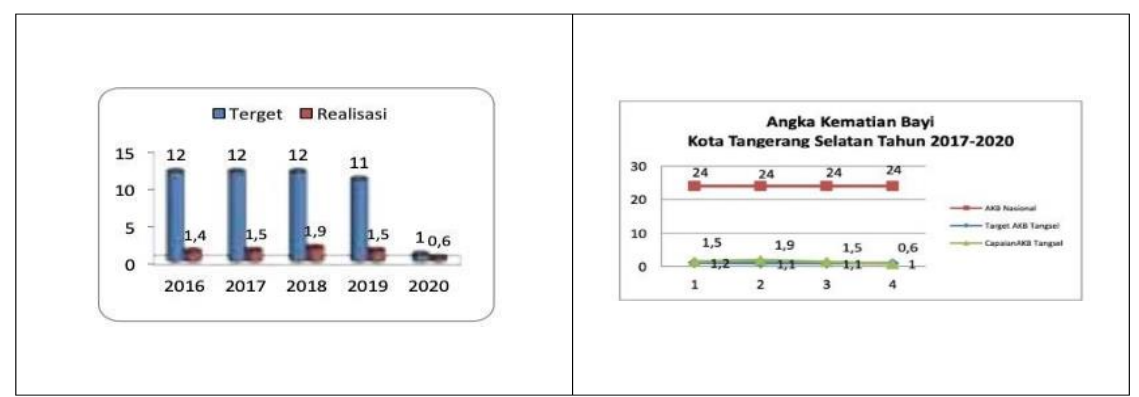

Source: https://dinkes.tangerangselatankota.go.id/uploads/lkip/10.pdf

Figure 2. Baby Mortality Rate in South Tangerang (2016-2020)

98.3\% pregnant women checking their pregnancy regularly in the Puskesmas. The South Tangerang City Health Office also strives to reduce the number of maternal mortality, which is referred to the number of mother deaths in pregnancy, childbirth and within 42 days (6 weeks) after giving birth. The following figure showed that the death rate of pregnant women in South Tangerang City decreased from 2016 to 2020, which was marked by a lower number of realizations than the target. This illustrates that adequate services are needed for pregnant women to get services according to standards to reduce mortality. In addition, supporting technology is needed that can monitor the health of pregnant women and media that can provide educational facilities during pregnancy to reduce mortality.

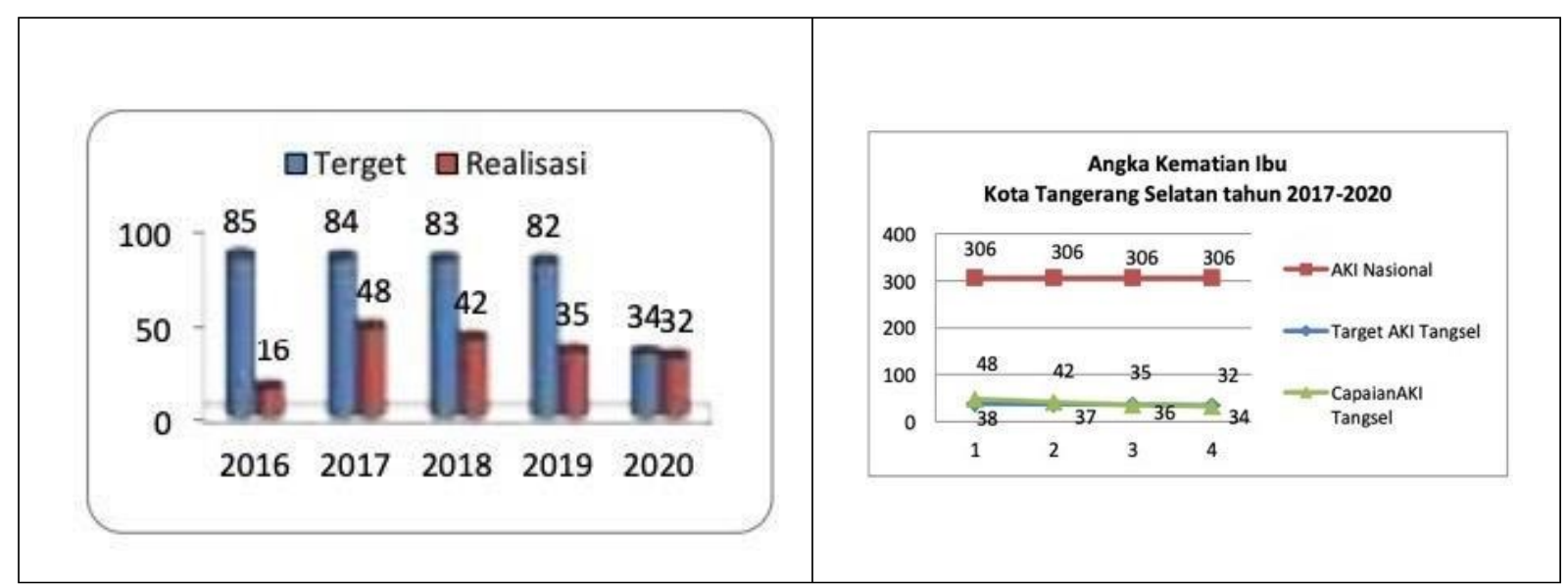

Source: https://dinkes.tangerangselatankota.go.id/uploads/lkip/10.pdf

Figure 3. Mother Mortality Rate in South Tangerang (2016-2020)

The South Tangerang City Health Office is certainly working hard to improve its services. Currently, the Tangerang City Health Office only has 31 health centers (Puskesmas) spread across several sub-districts with the average sick patient is 5.06 per day and average hospitalization in Puskesmas for 5.25 days (BPS South Tangerang City, 2019). There's a need to improve the degree of public health by developing supporting facilities and infrastructure that are able to provide better health services. Currently, South Tangerang City was appreciated as one of the smart city in Indonesia because of the usage of ICT in serving public. The technological innovation was expected could also be implemented in the healthcare services.

Si Pandai Kemas TangSel was developed as a technological breakthrough in giving more efficient ways to get the quick information at the real time. This mobile application will replace 
the manual procedure and provide accurate images and data information online. The mobile application will also reduce the time and location constraint since all Puskesmas in South Tangerang located in the scattered areas and made inefficient in making coordination exchange information. Si Pandai Kemas TangSel would also give the accurate and up-to-date data on the condition of mothers and children who are malnourished. With the technology system that will be built, it is expected that the Puskesmas can provide the latest information so that the TangSel DinKes can take appropriate action to overcome it, so that the death rate of mothers and children due to malnutrition can be suppressed.

In order to make sure that the mobile application Si Pandai Kemas Tangsel gave the best information of the updated data and could fulfill the expectation, the South Tangerang City Health Office conducted the survey using Unified Theory of Acceptance and Use of Technology (UTAUT) approach. This research is expected to measure the effectiveness of performance expectancy, effort expectancy, facilitating condition and habit in using Si Pandai Kemas TangSel mobile application.

\section{Literature Review and Hypothesis}

\subsection{Unified Theory of Acceptance and Use of Technology (UTAUT)}

The growth of technology has prompted several sectors including the health sector. The convenience offered by technology, such as the ability to use anytime and anywhere, can be adopted by its users to improve health aspects and monitor a person's health. Several health studies have been conducted related to technology adoption in healthcare, such as studies by Wei et al. (2020), Woldeyohannes \& Ngwenyama (2017) and Samoggia \& Riedel (2020) that apply the UTAUT (Unified Theory of Acceptance and Use of Technology) framework to measure the adoption of technology in healthcare industries. Many researchers adopt the UTAUT framework because it can describe two factors that influence user behavior, namely internal and external motivations, that encourage users to adopt a technology. These internal and external factors involve performance expectancy, effort expectancy, social influence, facilitating conditions, hedonic motivation, price value and habit (Venkatesh et al., 2012). Therefore, this study adopts the UTAUT research framework from Venkatesh et al. (2012) to understand the factors influencing health technology adoption. In this study, internal motivation factors adjusted to the user's characteristics are effort expectancy and habit. In contrast, external motivation is measured through performance expectancy, facilitating conditions and habit.

\subsection{Performance expectancy}

Technology has become a part of everyday life in recent times because many sectors adopt the technology. Some studies have learned a lot about technology adoption. Some scholars found that users' perceived usefulness will impact technology adoption. Performance expectancy is an individual's belief that technology will facilitate daily activities (Venkatesh et al., 2003). Several studies find that performance expectancy is a significant predictor of using the technology in the long term. The studies in financial technology explain that performance expectancy is a major driving factor in the adoption of technology (Rahi et al., 2019, Olivera et al., 2016, Morosan \& DeFranco, 2016; Chua et al., 2018). While research on social networks also found that the perceived benefits will drive users to continue using the technology (Chua et al., 2018). In healthcare with a minimum of health facilities offered, technology will help to facilitate health services. This technology provides several benefits for its users, such as saving waiting time when consulting with health professionals, ease in gaining information and health support. Khan \& Woosley (2011) state that the use of technology in health will facilitate medical 
personnel in monitoring the health of its users because it provides the variety of information needed. In addition, a study from Alam et al. (2020) also stated that for health technology, the main factor that affects a person's willingness to use the technology in the long term is performance expectancy. Hence, when users feel the benefits of the technology, it will encourage them to use the technology continuously (Lin et al., 2014). Other research in the field of a healthy lifestyle also supports that performance expectancy is a factor that affects the intention to use technology (Wei et al., 2020).

\section{H1: Performance expectancy positively influences behavior intention in using mobile health application.}

\subsection{Effort expectancy}

The adoption of technology will be readily accepted by its users if they feel the ease of using the features of the technology. According to Venkatesh et al. (2003), effort expectancy is the ease of using technology. When users only need a little effort in using technology, they will feel relief. Various previous studies have proven that effort expectancy is one factor that influences behavioural intention (Chaouali et al., 2016, Martins et al., 2014, Purnamaningsih et al., 2019). Gücin \& Berk (2015) stated that the ease of using an application is a critical factor that drives users to be willing to use the application in the long term. Consequently, the technology in health must consider the convenience for its users. To such an extent, with the findings from Okumus et al. (2018), health app users' readiness would increase if they felt the ease in operating it. Other research supports the result that the effort expectancy in the field of health technology is a factor that affects a user's to use such technology (Lee, S. and Lee, D. (2020), Alam et al., (2021) and Al Aufa et al., (2020).

\section{H2: Effort expectancy positively influences behavior intention in using mobile health application.}

By the side of technology, benefits perceived by a user are not limited to the function of the technology itself. Factor ease of use is also one of the factors that can build a perception of the beneficial effects for its user. Moreover, when users feel less effort when using technology, it will create the perception that the technology helps their day-to-day activities and thus provides benefits. Technology in the field of health also requires the same. Zhang et al. (2019) stated that the convenience perceived by health technology users would improve the perception of the beneficial benefits it deserves. It will drive the intention to use such technology in the long term. The user prefers simple and efficient technology in its use (Chua et al., 2018). Some previous studies from Akturan \& Tezcan et al. (2012), Lee et al. (2018) also found that effort expectancy is a predictor of performance expectancy.

\section{H3: Effort expectancy positively influences performance expectancy of mobile health application.}

\subsection{Facilitating Condition}

Facilitating conditioning is an individual's belief that the infrastructure it possesses supports technology adoption (Venkatesh, 2003). Particular technology has different infrastructure needs to support the usage of those technologies. For instance, applications in health support facilities that are much required are a sufficient internet connection, adequate smartphone and the ability and knowledge of using technology for its users.

Alam et al. (2021) also explained that the adoption of health technology such as applications 
would be readily accepted by its users if users have adequate support facilities such as smartphones, including internet support. Previous studies from Alam et al. 2020; Venkatesh et al., 2012; and Sobti, 2019 also confirm facilitating conditions that impact behavioural intention.

H4: Facilitating Condition positively influences behavior intention in using mobile health application.

\subsection{Habit}

According to Venkatesh et al. (2012), habit is a repetitive behaviour that derives from the learning process. It requires an initial strategy that helps users understand the use of technology. When such a learning process succeeds, users feel that this technology is easy to use. This perception then promotes repetitive behaviour. The more people become accustomed to using technology, the more they can use it continuously. Several previous studies also support, for instance, in the field of e-commerce (Liao et al., 2006 and Tak \& Panwar, 2017), financial technology (Raza et al. (2017), and research on technology adoption among students (Handoko, 2020) stated that habit is a factor affecting the intention of users in adopting technolog.

\section{H5: Habit positively influences behavior intention in using mobile health application.}

\subsection{Research Model}

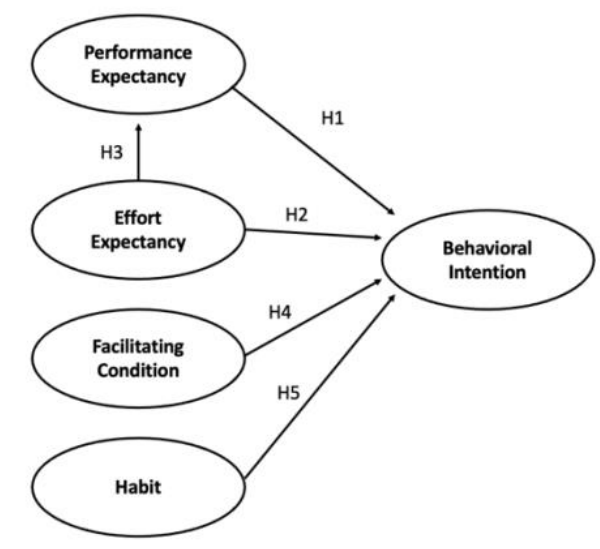

Figure 4. Research Model

\section{Research Methodology}

The research is cross-sectional quantitative research where the data collected taken from a sample population at specific moment of time, and the primary data was gathered using google form questionnaire during The Mother and Child Health Information System (SiPANDAI Kemas) socialization session to respective stakeholders on June 3, 2021. The survey was able to collect of 127 respondents. The sampling design was targeting the user of the mobile health application, namely: Healthcare staffs at Puskesmas Tangerang Selatan, expected mothers and mothers with babies and children age.

The inference analysis using PLS-SEM (Partial Leased Square - Structural Equation Model) were conducted to describe the respondent demography and to model the relationship between latent variables. In the inference analysis, there were two evaluations procedures were conducted: (1) measurement model evaluation model and structural evaluation model. The measurement model evaluation model examines the reliability and validity of construct measure 
such as internal consistency (Cronbach's alpha and composite reliability), convergent validity (indicator reliability, average variance extracted) and discriminant validity. (2) The Structural Model Evaluation which comprises the coefficient of determination $\left(\mathrm{R}^{2}\right)$, size and significance of path coefficients.

\section{Research Findings}

The descriptive analysis shows that most of the respondent was Female (93\%) in the age above 23 years with majority with age above 40 years. Most of the respondent group are consider pregnant mother $(19 \%)$, mother with infant $(20 \%)$, candidate $(17 \%)$, and officer of Health Service at Tangerang Selatan (49\%). The housewife (43\%), government officer (32\%) and private company employee (10\%) are most of the respondent job with education background ranging for primary school to graduate school with most of them had high school $(36 \%$ and undergraduate ( $42 \%$ ) education background.

\subsection{Inferential Analysis}

The research framework was modelled using a path model where Performance Expectation, Effort expectation and Facilitating condition are considered as the exogenous latent variable while the intention behavior is considered as the endogenous latent variable with bootstrap result depicted in the Figure.

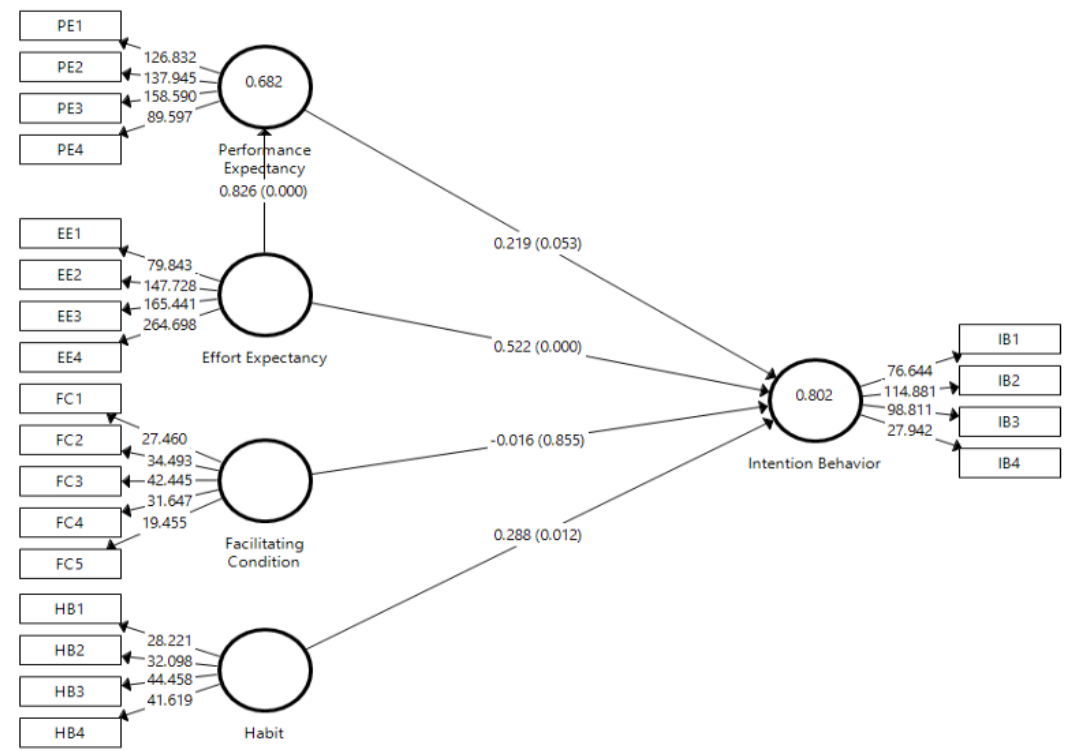

Figure 5. The Model Bootstrap Result

( $\mathrm{t}$ value for outer model, path coefficient and $\mathrm{p}$ value for inner model)

The evaluation of measurement model result was conducted as depicted in the Table 1 which comprises of Convergent Validity, Internal Consistency and Reliability and Discriminant validity evaluation. From The convergent validity evaluation all indicators are within the threshold where the loading factor above 0.72 , indicator reliability and AVE are above 0.5 where it means that the respective indicators can represent the construct they have. The internal consistency and reliability indicator's both composite reliability and Cronbach's Alfa have dissatisfactory result as the value are above the threshold. It means that the indicators measuring the same phenomena and not likely to be a valid measure of the construct (Hair et al., 2017). The discriminant validity shows a good result where the Heterotrait-monotrait (HTMT) ratio 
confidence level interval does not include 1 where it means in empirical standard each construct is truly distinct with other construct.

In the evaluation of structural model, there are five hypothesizes being evaluated as depicted in Table 2. There are two hypotheses that are not significant: H1 the relationship between Performance Expectancy with the Intention Behavior and $\mathrm{H} 4$ the relationship between Facilitating condition with the Intention Behavior while the rest of the hypothesis are significant with $\mathrm{p}$ value less than 0.05 . The path coefficients analysis shows that the relationship H3 between Effort expectancy with performance expectancy are the strongest relationship with path coefficient 0.826 and significant $p$ value 0.000 .

Table 1. The Evaluation of Measurement Model

\begin{tabular}{|c|c|c|c|c|c|c|c|}
\hline \multirow[b]{3}{*}{$\begin{array}{c}\text { Latent } \\
\text { Variable }\end{array}$} & \multirow[b]{3}{*}{$\begin{array}{c}\text { Indicat } \\
\text { or }\end{array}$} & \multicolumn{3}{|c|}{ Convergent Validity } & \multicolumn{2}{|c|}{$\begin{array}{l}\text { Internal Consistency } \\
\text { and Reliability }\end{array}$} & \multirow[b]{2}{*}{$\begin{array}{l}\text { Discrimina } \\
\text { nt Validity }\end{array}$} \\
\hline & & $\begin{array}{l}\text { Loadin } \\
\text { g }\end{array}$ & $\begin{array}{c}\text { Indicato } \\
\text { r } \\
\text { Reliabili } \\
\text { ty }\end{array}$ & AVE & $\begin{array}{c}\text { Composi } \\
\text { te } \\
\text { Reliabilit } \\
y\end{array}$ & $\begin{array}{l}\text { Cronbach } \\
\text { 's Alpha }\end{array}$ & \\
\hline & & $>0.72$ & $>0.50$ & $>0.50$ & $0.60-0.90$ & $0.60-0.90$ & $\begin{array}{c}\text { HTMT } \\
\text { confidence } \\
\text { interval } \\
\text { does not } \\
\text { include } 1\end{array}$ \\
\hline \multirow{4}{*}{$\begin{array}{l}\text { Effort } \\
\text { Expectanc } \\
\text { y }\end{array}$} & EE1 & 0.965 & 0.93 & \multirow{4}{*}{$\begin{array}{c}0.955 \\
6\end{array}$} & \multirow{4}{*}{0.9885} & \multirow{4}{*}{0.9845} & \multirow{4}{*}{ Yes } \\
\hline & EE2 & 0.979 & 0.96 & & & & \\
\hline & EE3 & 0.979 & 0.96 & & & & \\
\hline & EE4 & 0.987 & 0.97 & & & & \\
\hline \multirow{5}{*}{$\begin{array}{l}\text { Facilitatin } \\
\mathrm{g} \\
\text { Condition }\end{array}$} & $\mathrm{FC} 1$ & 0.863 & 0.74 & \multirow{5}{*}{$\begin{array}{c}0.801 \\
2\end{array}$} & \multirow{5}{*}{0.9526} & \multirow{5}{*}{0.9380} & \multirow{5}{*}{ Yes } \\
\hline & $\mathrm{FC} 2$ & 0.920 & 0.85 & & & & \\
\hline & FC3 & 0.942 & 0.89 & & & & \\
\hline & $\mathrm{FC} 4$ & 0.899 & 0.81 & & & & \\
\hline & FC5 & 0.848 & 0.72 & & & & \\
\hline \multirow{2}{*}{ Habit } & HB1 & 0.908 & 0.82 & \multirow{2}{*}{$\begin{array}{c}0.850 \\
5\end{array}$} & \multirow[b]{2}{*}{0.9579} & \multirow[b]{2}{*}{0.9419} & \multirow{2}{*}{ Yes } \\
\hline & HB2 & 0.933 & 0.87 & & & & \\
\hline
\end{tabular}




\begin{tabular}{|c|c|c|c|c|c|c|c|}
\hline \multirow{5}{*}{$\begin{array}{c}\text { Latent } \\
\text { Variable }\end{array}$} & & \multicolumn{3}{|c|}{ Convergent Validity } & \multicolumn{2}{|c|}{$\begin{array}{l}\text { Internal Consistency } \\
\text { and Reliability }\end{array}$} & \multirow[b]{2}{*}{$\begin{array}{l}\text { Discrimina } \\
\text { nt Validity }\end{array}$} \\
\hline & & $\begin{array}{l}\text { Loadin } \\
\text { g }\end{array}$ & $\begin{array}{c}\text { Indicato } \\
\mathbf{r} \\
\text { Reliabili } \\
\text { ty }\end{array}$ & AVE & $\begin{array}{c}\text { Composi } \\
\text { te } \\
\text { Reliabilit } \\
y\end{array}$ & $\begin{array}{c}\text { Cronbach } \\
\text { 's Alpha }\end{array}$ & \\
\hline & $\begin{array}{c}\text { Indicat } \\
\text { or }\end{array}$ & $>0.72$ & $>0.50$ & $>0.50$ & $0.60-0.90$ & $0.60-0.90$ & $\begin{array}{c}\text { HTMT } \\
\text { confidence } \\
\text { interval } \\
\text { does not } \\
\text { include } 1\end{array}$ \\
\hline & HB3 & 0.919 & 0.84 & & & & \\
\hline & HB4 & 0.929 & 0.86 & & & & \\
\hline \multirow{4}{*}{$\begin{array}{l}\text { Intention } \\
\text { Behavior }\end{array}$} & IB1 & 0.964 & 0.93 & \multirow{4}{*}{$\begin{array}{c}0.907 \\
8\end{array}$} & \multirow{4}{*}{0.9752} & \multirow{4}{*}{0.9660} & \multirow{4}{*}{ Yes } \\
\hline & IB2 & 0.961 & 0.92 & & & & \\
\hline & IB3 & 0.959 & 0.92 & & & & \\
\hline & IB4 & 0.927 & 0.86 & & & & \\
\hline \multirow{4}{*}{$\begin{array}{l}\text { Performan } \\
\text { ce } \\
\text { Expectanc } \\
\text { y }\end{array}$} & PE1 & 0.973 & 0.95 & \multirow{4}{*}{$\begin{array}{c}0.945 \\
6\end{array}$} & \multirow{4}{*}{0.9858} & \multirow{4}{*}{0.9808} & \multirow{4}{*}{ Yes } \\
\hline & PE2 & 0.975 & 0.95 & & & & \\
\hline & PE3 & 0.980 & 0.96 & & & & \\
\hline & PE4 & 0.962 & 0.93 & & & & \\
\hline
\end{tabular}

Table 2 The Evaluation of Structural model

\begin{tabular}{|c|c|c|c|c|c|}
\hline $\mathbf{H}$ & Relationship & $\begin{array}{c}\text { Path } \\
\text { Coefficien } \\
\text { ts }\end{array}$ & $\begin{array}{c}\text { t- } \\
\text { Value } \\
\text { s }\end{array}$ & $\begin{array}{c}\text { P- } \\
\text { Value } \\
\text { s }\end{array}$ & $\begin{array}{c}\text { Significa } \\
\text { nt } \\
(\mathbf{p}<\mathbf{0 . 0 5})\end{array}$ \\
\hline $\begin{array}{c}\mathrm{H} \\
1\end{array}$ & $\begin{array}{l}\text { Performance Expectancy }->\text { Intention } \\
\text { Behavior }\end{array}$ & 0.219 & 1.932 & 0.053 & No \\
\hline $\begin{array}{l}\mathrm{H} \\
2\end{array}$ & Effort Expectancy -> Intention Behavior & 0.522 & 4.552 & 0.000 & Yes \\
\hline $\begin{array}{l}\mathrm{H} \\
3\end{array}$ & $\begin{array}{l}\text { Effort Expectancy } \quad->\quad \text { Performance } \\
\text { Expectancy }\end{array}$ & 0.826 & $\begin{array}{r}13.23 \\
5\end{array}$ & 0.000 & Yes \\
\hline
\end{tabular}




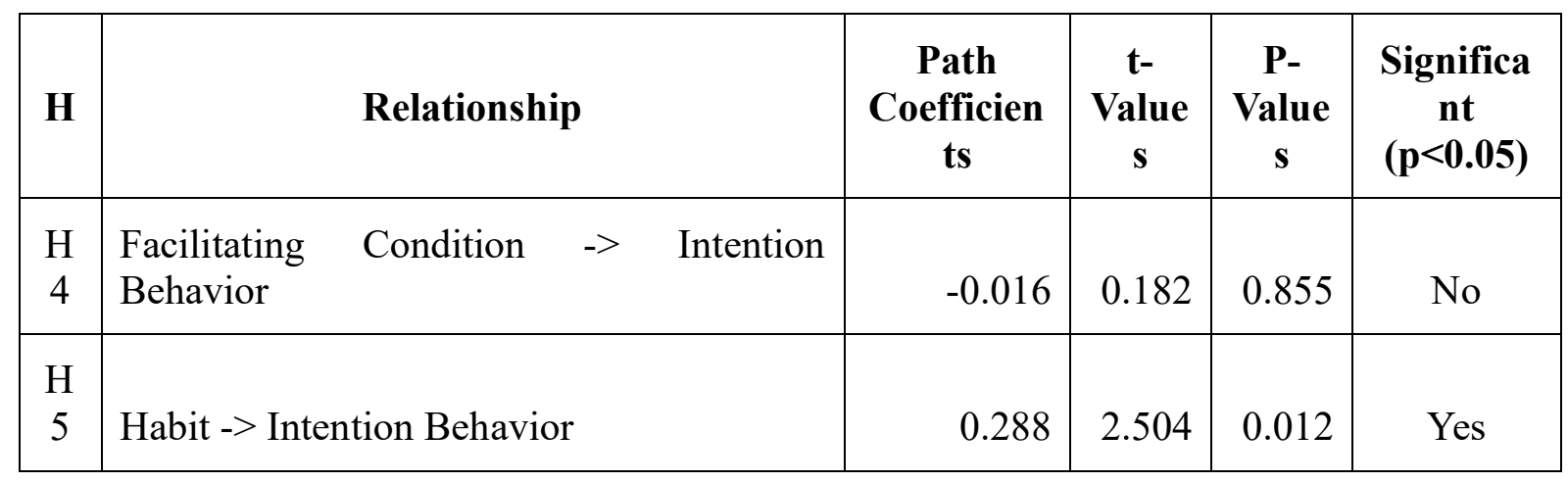

Table 3 Coefficient of Determination (R2 value)

\begin{tabular}{|l|c|c|}
\hline & R Square & $\begin{array}{l}\text { R Square } \\
\text { Adjusted }\end{array}$ \\
\hline Intention Behavior & 0.80 & 0.80 \\
\hline $\begin{array}{l}\text { Performance } \\
\text { Expectancy }\end{array}$ & 0.68 & 0.68 \\
\hline
\end{tabular}

The evaluation of coefficient of determination (R2 value) as depicted in

Table 3 shows that $80 \%$ the current exogenous variable such as Performance Expectancy, Effort Expectancy, Facilitating Condition and Performance Expectancy represent the 80\% change of the Intention Behavior while the 68\% change in the Performance Expectation caused by the Effort Expectancy.

\section{Discussion and Managerial Implications}

Si Pandai Kemas application users are pregnant mothers, toddlers, babies, and adolescents in the South of Tangerang. We know that educating using a health app is not easy. Given the many trends related to health issues, more people prefer to meet health professionals directly than online consultation through an app. Si Pandai Kemas App also faced the same situation as the newly launched app in June 2021. This app aims to help pregnant mothers, mothers who have toddlers and babies, and adolescents get support from healthcare and various health information needed. However, many challenges are faced to encourage local communities to use the application. Therefore, it takes a few strategies that pregnant mothers, mothers who have toddlers and babies and adolescents can adopt these applications in the long term.

The results of this study reveal some findings. First, increasing the effort expectancy can increase the intention to use Si Pandai Kemas app. The ease of use encourages increased adoption of technology and the perception of the benefits of its users. Hence, it is necessary to increase the ease of use of an application. Second, in this study, habits also influenced the increased adoption of the application. For that reason, the application's ease of use and growing habits in using the application needs to be enhanced to support health assistance. Third, the study found that performance expectancy and facilitating conditions did not affect behavioral intention. The experience of using application is become a mandatory requirement for further 
adoption (Utomo, 2021).

The findings from this study indicate that effort expectancy affects the user's intention to adopt technology in the long term. The findings are in line with research by Okumus et al. (2018), Lee, S. and Lee, D. (2020), and Alam et al., (2021). The ability to use an app becomes the primary driving force for the user to adopt a technology. Considering for a patient, using this technology is voluntary, not an obligation like an employee in a company that has used a particular technology. Therefore, It requires effort to encourage them to use the application. For these apps, we can increase the intention to use through the development of the User Interface (UI) and User Experience (UX) according to the characteristics of the user. UI and UX are the first interactions of a user with an application then it has become an essential part of the application. UI and UX development focuses on usability and identity (Ji et al., 2018). For the UI of the application, the Si Pandai Kemas app can present an exciting design with colours that can describe the characteristics of its user. An impression on the initial appearance needs to be made to attract the attention of its users. At the same time, UX related to usability can be done by developing easy-to-access features by supplementing clear, easy-to-understand instructions to reduce user errors when accessing the application. The availability of feature guidance is required to make it easier for the user when using an application. For this purpose, the app can conduct surveys to users regularly to ensure that the features have been sufficient and easy to use. The update process can be continued for better results.

The study also looked at the habit factors encouraging users to adopt technology in the long run. These findings align with Liao et al., 2006; Tak \& Panwar, 2017; and Raza et al. (2017). It indicates that the more users are accustomed to using technology, the higher the chances that the application will be used in the long run. However, retaining users and encouraging them to continue using is challenging, especially for new applications. According to Yen et al. (2016), Habit is an automated response of an individual triggered by specific stimuli resulting from the learning process that does not require cognitive analysis. In order to improve the usage habits of the application, it is necessary to conduct regular education in advance towards its users. Then they can more easily understand and become accustomed to using the application when they need the required health services. Given the increasing experience of a person with technology will open up the opportunity to strengthen user habits. Although users have been accustomed to using various other applications, a new application requires a process of recognition and effort to cultivate habits in using when needed. Higher engagement with such applications will create more knowledge and accustomed to using.

In addition, the study found that performance expectancy and facilitating conditions did not affect the intention to adopt the technology. The study results align with Kwateng et al. (2019) findings, stating that performance expectancy does not influence behavioral intention. It shows that the perception of the app's benefits is not enough as a driving factor to adopt the technology. The ease of using the application for the primary users becomes a significant factor. It can happen because users feel that if the app is not relatively easy to use, they can still get services from healthcare providers through live visits. Then, the benefits of this application become less affecting its users to adopt the app. In addition, this study also explains that facilitating conditions do not influence behavioral intentions. The results of this study are consistent with Talukder's study (2020) that states that facilitating conditions does not affect behavioral intentions. The average user already has enough equipment and knowledge to operate an application on the app.; therefore, it is not the main factor influencing them to use a new app. They consider the ease of use application to adopt the app. 


\section{Acknowledgments}

The author would like to say thank you to Universitas Multimedia Nusantara and Dinas Kesehatan Tangerang Selatan that give financial support in this research, under the contract No. 1551/PKMI/LPPM-UMN/III/2021.

\section{References}

Akturan, U., \& Tezcan, N. (2012). Mobile banking adoption of the youth market: Perceptions and intentions. Marketing Intelligence \& Planning, 30(4), 444-459. https://doi.org/10.1108/02634501211231928

Alam, M. Z., Hoque, M. R., Hu, W., \& Barua, Z. (2020). Factors influencing the adoption of mHealth services in a developing country: A patient-centric study. International Journal of Information Management, 50, 128-143.

Alam, M. M. D., Alam, M. Z., Rahman, S. A., \& Taghizadeh, S. K. (2021). Factors influencing mHealth adoption and its impact on mental well-being during COVID-19 pandemic: A SEMANN approach. Journal of Biomedical Informatics, 116, 103722.

Al Aufa, B., Renindra, I. S., Putri, J. S., \& Nurmansyah, M. I. (2020). An application of the Unified Theory of Acceptance and Use of Technology (UTAUT) model for understanding patient perceptions on using hospital mobile application. Enfermería Clínica, 30, 110113. https://doi.org/10.1016/j.enfcli.2020.06.025

Biro Pusat Statistik (2019). Survei Sosial Ekonomi Nasional (Susenas) Kor 2018. https://sirusa.bps.go.id/sirusa/index.php/dasar/pdf?kd=1558\&th=2018

BPS Kota Tangerang Selatan (2019). Kota Tangerang Selatan Dalam Angka 2019.

Chaouali, W., Yahia, I. B., \& Souiden, N. (2016). The interplay of counter-conformity motivation, social influence, and trust in customers' intention to adopt Internet banking services: The case of an emerging country. Journal of Retailing and Consumer Services, 28, 209218.

Chua, P. Y., Rezaei, S., Gu, M. L., Oh, Y., \& Jambulingam, M. (2018). Elucidating social networking apps decisions: performance expectancy, effort expectancy and social influence.

Nankai Business Review International.

Dinas Kesehatan Tangerang Selatan (2019). Renstra Dinkes 2016-2021.

Dinas KomInfo Kota Tangerang Selatan (2019). Survei dan Kompilasi Produk Administrasi Bidang Sosial tahun 2017.

Dinas KomInfo Kota Tangerang Selatan (2019). Data dan Statistik Bidang Sosial Kota Tangerang Selatan tahun 2018.

Gücin, N. Ö., \& Berk, Ö. S. (2015). Technology acceptance in health care: an integrative review of predictive factors and intervention programs. Procedia-Social and Behavioral Sciences, 195, 1698-1704.

Handoko, B. L. (2020, August). UTAUT 2 model for entrepreneurship students on adopting technology. In 2020 International Conference on Information Management and Technology (ICIMTech) (pp. 191-196). IEEE. doi: 10.1109/ICIMTech50083.2020.9211185

Hair, J. F., Hult, G. T. M., Ringle, C. M., \& Sarstedt, M. (2017). A Primer on Partial Least 
Squares Structural Equation Modeling (PLS-SEM).

Utomo, P. (2021). The Innovation and Technology Role in Marketing 5.0. In GCAINDO (Ed.), E-Marketing: Principles, Dynamics \& Optimization (p. 18). Diandra Kreatif/Mirra Buana Media.

Ji, H., Yun, Y., Lee, S., Kim, K., \& Lim, H. (2018). An adaptable UI/UX considering user's cognitive and behavior information in distributed environment. Cluster Computing, 21(1), 1045-1058. https://doi.org/10.1007/s10586-017-0999-9

Kementerian Kesehatan (2017). Peraturan Menteri Kesehatan Republik Indonesia No.46, tahun 2017 tentang Strategi e-Kesehatan Nasional.

Khan, A., \& Woosley, J. M. (2011). Comparison of contemporary technology acceptance models and evaluation of the best fit for health industry organizations. IJCSET, 1(11), 709-717.

Kurniasari, et.al (2020). The Effect of Perceived Usefulness, Perceived Ease of Use, Trust, Attitude and Satisfaction Into Continuance of Intention in Using Alipay. Management \& Accounting Review, Vol. 19, No.2, pp. 28-39.

Kwateng, K. O., Atiemo, K. A. O., \& Appiah, C. (2019). Acceptance and use of mobile banking: an application of UTAUT2. Journal of Enterprise Information Management. https://doi.org/10.1108/JEIM-03-2018-0055

Lee S-J, Choi MJ, Rho MJ, Kim D-J and Choi IY (2018) Factors Affecting User Acceptance in Overuse of Smartphones in Mobile Health Services: An Empirical Study Testing a Modified Integrated Model in South Korea. Front. Psychiatry 9:658. doi: $\quad$ 10.3389/fpsyt.2018.00658

Lee, S. M., \& Lee, D. (2020). Healthcare wearable devices: an analysis of key factors for continuous use intention. Service Business, 14(4), 503-531. https://doi.org/10.1007/s11628020-00428-3

Liao, C., Palvia, P., \& Lin, H. N. (2006). The roles of habit and web site quality in e-commerce. International Journal of Information Management, 26(6), 469-483. https://doi.org/10.1016/j.ijinfomgt.2006.09.001.

Lin, S. P., Hsieh, C. Y., \& Ho, T. M. (2014). Innovative healthcare cloud service model. In Applied Mechanics and Materials (Vol. 543, pp. 4511-4513). Trans Tech Publications Ltd. https://doi.org/10.4028/www.scientific.net/AMM.543-547.4511

Martins, C., Oliveira, T., \& Popovič, A. (2014). Understanding the Internet banking adoption: A unified theory of acceptance and use of technology and perceived risk application.

International journal of information management, 34(1), 1-13. https://doi.org/10.1016/j.ijinfomgt.2013.06.002

Morosan, C., \& DeFranco, A. (2016). It's about time: Revisiting UTAUT2 to examine consumers' intentions to use NFC mobile payments in hotels. International Journal of Hospitality Management, 53, 17-29. https://doi.org/10.1016/j.ijhm.2015.11.003

Okumus, B., Ali, F., Bilgihan, A., \& Ozturk, A. B. (2018). Psychological factors influencing customers' acceptance of smartphone diet apps when ordering food at restaurants. International Journal of Hospitality Management, 72, 67-77. https://doi.org/10.1016/j.ijhm.2018.01.001

Oliveira, T., Thomas, M., Baptista, G. and Campos, F. (2016), "Mobile payment: Understanding the determinants of customer adoption and intention to recommend the technology", Computers 
in Human Behavior, Vol. 61, pp. 404-414. https://doi.org/10.1016/j.chb.2016.03.030

Purnamaningsih, P., Erhan, T. P., \& Rizkalla, N. (2019). BEHAVIORAL INTENTION TOWARDS APPLICATION-BASED SHORT-DISTANCE DELIVERY SERVICES ADOPTION IN INDONESIA. Review of Behavioral Aspect in Organizations and Society, 1(1), 77-86. https://doi.org/10.32770/rbaos.vol177-8

Rahi, S., Mansour, M. M. O., Alghizzawi, M., \& Alnaser, F. M. (2019). Integration of UTAUT model in internet banking adoption context: The mediating role of performance expectancy and effort expectancy. Journal of Research in Interactive Marketing. https://doi.org/10.1108/JRIM-02-2018-0032.

Raza, S. A., Shah, N., \& Ali, M. (2019). Acceptance of mobile banking in Islamic banks: evidence from modified UTAUT model. Journal of Islamic Marketing. https://doi.org/10.1108/JIMA-04-2017-0038

Samoggia, A., \& Riedel, B. (2020). Assessment of nutrition-focused mobile apps' influence on consumers' healthy food behaviour and nutrition knowledge. Food Research International, 128, 108766. https://doi.org/10.1016/j.foodres.2019.108766

Setiawati, M.E. \& Nurrizka, R.H. (2019). Evaluasi Pelaksanaan Sistem Rujukan Berjenjang Dalam Program Jaminan Kesehatan Nasional. Jurnal Kebijakan Kesehatan Indonesia: JKKI, UGM, Vol.8, 01 Maret 2019, hal. 35-40.

Sobti, N. (2019). Impact of demonetization on diffusion of mobile payment service in India: Antecedents of behavioral intention and adoption using extended UTAUT model. Journal of Advances in Management Research. https://doi.org/10.1108/JAMR-09- 2018- 0086

Talukder, M. S., Sorwar, G., Bao, Y., Ahmed, J. U., \& Palash, M. A. S. (2020). Predicting antecedents of wearable healthcare technology acceptance by elderly: A combined SEM-Neural Network approach. Technological Forecasting and Social Change, 150, 119793. https://doi.org/10.1016/j.techfore.2019.119793

Tak, P., \& Panwar, S. (2017). Using UTAUT 2 model to predict mobile app based shopping: evidences from India. Journal of Indian Business Research. https://doi.org/10.1108/JIBR-112016-0132

Utomo, P. (2021). The Innovation and Technology Role in Marketing 5.0. In GCAINDO (Ed.), E-Marketing: Principles, Dynamics \& Optimization (p. 18). Diandra Kreatif/Mirra Buana Media.

Venkatesh, V., et al.: User acceptance of information technology: toward a unified view. MIS Q. 27, 425-478 (2003). https://doi.org/10.2307/30036540

Venkatesh, V., Thong, J.Y., Xu, X.: Consumer acceptance and use of information technology: extending the unified theory of acceptance and use of technology. MIS Q. 36, 157-178 (2012). https://doi.org/10.2307/41410412

Wei, J., Vinnikova, A., Lu, L., \& Xu, J. (2020). Understanding and predicting the adoption of fitness mobile apps: evidence from China. Health communication, 1-12. https://doi.org/10.1080/10410236.2020.1724637

Woldeyohannes, H. O., \& Ngwenyama, O. K. (2017, July). Factors influencing acceptance and continued use of mHealth apps. In International Conference on HCI in Business, Government, and Organizations (pp. 239-256). Springer, Cham. https://doi.org/10.1007/978-3-319-58481- 
$2 \_19$

Yen, Y. S., \& Wu, F. S. (2016). Predicting the adoption of mobile financial services: The impacts of perceived mobility and personal habit. Computers in Human Behavior, 65, 31-42. https://doi.org/10.1016/j.chb.2016.08.017

Zhang, Y., Liu, C., Luo, S., Xie, Y., Liu, F., Li, X., \& Zhou, Z. (2019). Factors influencing patients' intentions to use diabetes management apps based on an extended unified theory of acceptance and use of technology model: web-based survey. Journal of medical Internet research, 21(8), e15023. doi:10.2196/15023

\section{Copyrights}

Copyright for this article is retained by the author(s), with first publication rights granted to the journal.

This is an open-access article distributed under the terms and conditions of the Creative Commons Attribution license (http://creativecommons.org/licenses/by/4.0/). 